\title{
Sigfried Giedion's Chicago School: A Midpoint in 150 Years of History
}

\author{
Authors: Dan C. Baciu. \\ Affiliations: University of California Santa Barbara Department of English, Santa \\ Barbara, CA 93106, USA. University of California Santa Barbara Department of History \\ of Art and Architecture, Santa Barbara, CA 93106, USA.
}

Email: books (at) yahoo.com ORCID: 0000-0002-0043-5616

Abstract: Sigfried Giedion (1888-1968) was a foremost Swiss architectural historian. Teaching at Harvard, Yale, MIT, the Chicago School of Design, and at ETH Zurich, he deeply shaped the idea of modern architecture. One of Giedion's best known works was his book chapter on the Chicago school. It was a key piece of historiography, embedded in the broader context of his famous publication of 1941, "Space, Time and Architecture." However Giedion's historic sources for the Chicago school were long believed to be lost or absent, which made his historiography target of endless academic debates. One writer called it a "monumental error," another "abuse," and yet another a "myth." This present article recovers Giedion's sources, and it also evaluates the role of his publication in a larger history of cultural diversification and growth: After Giedion's work appeared, multiple schools of thought all named "Chicago school" unexpectedly rose to prominence together. Many of these schools already existed decades before the 1940s, but they were less well known than thereafter. Why did this collective growth only come into action after such an extended period of formation? What was Giedion's role in the process? To study these questions, I developed a theory of cultural dissemination and reception that makes statements about the interplay between entire groups of authors and audiences. The theory builds on evolutionary models extensively studied in other disciplines. In the humanities, the theory may help us understand processes of formation and growth. In our particular case, Giedion's historiography was not only a midpoint but also a turning point in century-long process of diversification. As a more general finding, the broad validity of the causal model developed here suggests that the world around us is often shaped by similar principles of selforganization.

Keywords: Cultural Diversification; Cultural Life; Cultural Dissemination and Reception; Chicago Skyscrapers; Space, Time and Architecture; A.D.F. Hamlin; Felix Auerbach; Alfred Lotka; George Zipf. 


\section{Introduction}

Among the architectural historians of the modern movement, Sigfried Giedion was the most internationally active. Born in Prague to Swiss-Jewish parents, Giedion studied in Vienna and Munich, where he earned his doctorate under Heinrich Wölfflin. ${ }^{1}$ A luminary in early modern art history, Giedion's mentor taught methods for the comparative study art. Wölfflin juxtaposed artworks taken from different time periods and geographical settings, evaluating formal similarities and differences between them. This comparative approach went hand in glove with applied psychology that added a new, scientific perspective to art and architectural history. Giedion later adapted juxtapositions of images from in-class lecturing to print publications, ${ }^{2}$ and he found his own voice as spokesman in a network of artists and architects who united art and science in the service of cultural transformation. The scientific worldviews of the Vienna school together with Bauhaus design and Gestalt psychology formed some of the greatest achievements of this midcentury European vanguard that surrounded the enthusiastic Czech-Swiss historian.

Immigrating to the United States in 1938 at age 50, Giedion expected to publish a global history of architecture and industrialization, tentatively titled "The Life of Architecture." ${ }^{3}$ When weaving American architecture into his narrative, he emphasized the importance of the Chicago school as a future-oriented movement in the late 19th century.

The Chicago school was one of the happy moments in American architecture, in no other country could be seen in the 15 years between $1879-1893$ such a vigor to push into the future as shown by the Chicago school. ${ }^{4}$

These laudatory lines, used by Giedion to open a symposium held at New York University (NYU) in 1939, certainly attracted and pleased the general audience, but they also entangled Giedion into a dispute that he may not have fully foreseen. Giedion praised the Chicago school as a future-oriented movement that took place in the late 19th century. However, in doing so, he adopted a position that strengthened partisanship between New Yorkers and Chicagoans over who built the first skyscrapers, and, most importantly, contradicted most grand narratives of American architecture written by noteworthy American contemporaries. In 1939, only few Americans equated the history of the Chicago school with the rise of early Chicago skyscrapers.

A few months later, the United States National Council of Architectural Registration Boards (NCARB) undertook to write Giedion and discredit how he and his fellow emigrant László Moholy-Nagy used the term Chicago school. The NCARB called their perspective a "monumental error." Giedion read the letter attentively, as can be inferred from the numerous markings. The ensuing animosities, although bitter in their 
personal implications, are a beautiful reminder that no single author is in control of culture in its entirety. Rather, culture is the integration of diverse cultural perspectives, a lesson that could already have been taken from Wöllfin's comparative methods.

\section{Differences and Polarization}

The chronological setting "the 15 years between 1879-1893" that Giedion insisted on at NYU renders his historiography incompatible with most other contemporary writing. The NCARB, for example, defined the Chicago school as a group of pioneers in architectural licensing first established in the state of Illinois in 1897. These architects prided themselves for their sleek suburban mansions designed in the 1900s and 1910s.

Giedion opposed this view. He countered, "Many of [the Chicago architects who worked in the 1900s] lost the force which they had shown in a more favorable period." ${ }^{6}$ Back in the 1880s, an earlier generation of Chicago architects had taken advantage of ruthless speculation and construction boom; and they built the very first skyscrapers in the center of the city.

The Leiter building, completed by William Le Baron Jenney in 1879, is the earliest Chicago design that Giedion chose to include in his narrative (Fig.1a). This tall department store featured elevators and a facade that was beautiful and functional alike. Slender iron construction and terracotta cladding techniques made generous fenestration possible while also allowing for creative ornaments. Applied material science gave way to bold, new design solutions. Yet, the architectural breakthrough went beyond esthetics and design. Science created entire new potentialities for Chicago's urban and cultural life. Office buildings, hotels, and theaters together set the stage for a new, American way of life.

The Auditorium Building, completed by Adler \& Sullivan in 1889, helps substantiate Giedion's thesis (Fig.1b). This tall structure was as at once a tall office building, a modern hotel, and a theater featuring a beautifully designed golden arch with gold shimmering light bulbs. The building was a stunning feat of engineering, a symbol of urban life, and a home for the arts. Chicago's unison of art and science, and its success in the 1880s, was a lesson the vanguard could cherish.

Certainly, many American architects shared this fascination, but few of them called this particular piece of history "Chicago school." Giedion did not concede. After traveling to Chicago in January 1939, he could not wait to have his first research results published in a newly founded magazine Focus. ${ }^{7}$ At Harvard University, Giedion devoted one of his Charles Eliot Norton lectures to the Chicago school, ${ }^{8}$ and, in parallel, he organized the symposium mentioned above at NYU. ${ }^{9}$ Finally, "The Chicago School" entered as a chapter into his American magnum opus titled Space, Time, and Architecture. ${ }^{10}$ 
One by one, students found interest in Giedion's Chicago school. One of them was John A. Holabird, a Harvard student born into one of the most influential families of architects in Chicago. Naturally, he first met Giedion through his father's company in 1939. ${ }^{11}$ Nevertheless, the atmosphere at Harvard proved important. The younger Holabird really began to appreciate the European historian after hearing about the Chicago school from a classmate:

I wasn't even aware of the Chicago School until one of my classmates from Harvard came to me and said 'I want to see the Chicago School,' and I said 'What do you mean by the Chicago School?', 'Well, I have a book here on the Chicago School.' So all of a sudden we marched around and I showed him the buildings. This was 1939-1940. Giedion had recently lectured at Harvard. ${ }^{12}$

The lucky Harvard student who walked through the streets of Chicago next to John A. Holabird with a first edition of Space, Time and Architecture in their hands remains unidentified, but the Italian-Jewish historian Bruno Zevi was another Harvard student who became interested in the Chicago school.

Only few years later, Zevi published a survey of architectural history in Italian, and he acknowledged his professor's influence. Zevi admitted that he "did not do anything else other than translating Space, Time and Architecture."13 With respect to the Chicago school, Zevi's thesis was that the Chicago school had "overcome the schism between art and technology, ${ }^{14}$ which is what Giedion had also posited.

Furthermore, Zevi stands witness for Giedion's broader success. He wrote that Space, Time and Architecture was widely circulated and heavily used by many of his peers.

We all continuously have his Space, Time and Architecture under our eyes, and from it, we draw the elements of narration and the source material for our books. ${ }^{15}$

Some historians simply expanded on Giedion's work. Carl Condit, a local Chicago professor, turned Giedion's chapter on the Chicago school into an entire book, The Rise of the Skyscraper. ${ }^{16}$ The expanded version of this book, aptly titled The Chicago School of Architecture, ${ }^{17}$ became a standard work for local preservationists. When a student later interviewed Condit, asking about his historical sources, he mentioned Giedion's chapter on the Chicago school. ${ }^{18}$

Other followers include the famous historians Colin Rowe, Ludwig Hilberseimer, and Manfredo Tafuri: Rowe wrote an influential essay; ${ }^{19}$ Hilberseimer was a European friend of Giedion's to publish a survey of architecture and urban planning; ${ }^{20}$ and Tafuri 
opened a new perspective on the Chicago school, famously calling the skyscrapers "disenchanted mountains." 21

Still another survey of architecture that borrowed from Giedion was Henri Russell Hitchcock's American Architecture: Nineteenth and Twentieth Centuries. ${ }^{22}$ Yet, Hitchcock did not use the term Chicago school consistently, repeatedly changing his mind over the course of his career.

The cultural richness that the Chicago school embodies becomes particularly evident when studying competing historiographies and occasional conflict. Despite the letter that Giedion received from the NCARB, he never offered a full set of historical sources that would have settled the debate. Instead, his historiography became a beloved target for attackers.

For many decades, scholars outside Giedion's circles continued criticizing the lack of proper sources, perpetuating the view of the NCARB. ${ }^{23}$ Authors in this lineage claimed primacy and legitimized their assaults by stating that Thomas Tallmadge first "coined the term Chicago school in 1908;" 24 and Tallmadge had written that the Chicago school had started (not ended) in 1893. Here again, the historical setting chosen by Giedion proves critical.

Tallmadge attracted many followers, including Henry Russell Hitchcock and Philip Johnson of New Yorks Museum of Modern Art (MoMA) as well as the historian Hugh Morrison and his students Mark Peisch and H. Allen Brooks. Among these voices, Peisch and Brooks most openly opposed Giedion. In some of their publications, they treated Giedion's definition of the Chicago school as an abusive new convention. ${ }^{25}$

Brooks became a particularly outspoken critic when he witnessed that the term Chicago school acquired many senses that were clearly distinguishable from each other. He interpreted this cultural richness as problem that had to be abated. More recently, Robert Bruegmann and Joanna Merwood-Salisbury called Giedion's Chicago school the birth of a "myth," ${ }^{26}$ criticizing the apparent lack of historic sources, although also admitting the narrative's great history of reception. ${ }^{27}$ Thus, what the NCARB initially called a "monumental error," was later called "abuse," and still later "myth."

Ironically, attentive reading of Tallmadge's article reveals that Brooks' critique is grounded on one important false assumption. Tallmadge himself acknowledged that the idea of the Chicago school had come from elsewhere. ${ }^{28}$ Tallmadge did not coin the term Chicago school in 1908; he redefined it for his own purpose. Thus, Tallmadge's historiography does not exclude Giedion's.

\section{Dissonance and Diversification}

The cognitive dissonance that Brooks experienced requires further attention. Next to the old question whether there are historical sources that justify Giedion's defi- 
nition of the Chicago school, a new question arises: Regardless of justification, how did the Chicago school evolve, branch, and split?

This present article proceeds in two steps. First (Sections 3-5), Giedion's sources are recovered and interpreted in their larger cultural context that stretches well beyond architecture to philosophy, sociology, and other fields of cultural and academic endeavor.

Second (Sections 6-9), the history of the Chicago school is used as a source of scientific experience from which a new theory of cultural diversification is developed. Here, special attention is given to Giedion's role in this larger cultural diversification process. Methodologically, this second part further develops ideas about cultural change that have distant roots in Wölfflin and Giedion's times. However, these ideas need to be elaborated and operationalized to become testable against quantitative data.

\section{How Giedion Made up His Mind}

Millions were made when millions attended the World's Columbian Exposition held in the South of Chicago in 1893 (Fig.2e). This lush Chicago summer culminated in much-recounted stories of amusement and amazement. Yet, historians also choose this exuberant event to demarcate a historical break: The Chicago fair of 1893 separates the construction boom of the 1880s from the ensuing financial depression; and it separates early skyscraper designs from subsequent revivalist architecture. Within this grand scheme of history, Giedion placed the Chicago school before the Chicago fair. Confident in this choice, he cast his historiography in drama and pathos:

At the very moment when the Chicago school gained a mastery of the new means which it had created, its further development and influence were abruptly chocked off. The event that directly affected this change was the Chicago World's Fair of 1893. [...] While I was in Chicago, one architect who had worked on it quoted from memory the rather ironical comment of William James: "Everyone says one ought to sell al one has and mortgage one's soul to go there; it is esteemed such a revelation of beauty. People cast away all sin and baseness, burst into tears and grow religious, etc., under the influence." [...] The lonely American voices raised against the unexampled seduction of the public taste underlying the Fair's pseudo-splendor went unheard. ${ }^{29}$

"Pseudo-splendor" and "unexampled seduction" are words that Giedion may have chosen to render his historiography more acute. Nevertheless, there is a personal touch to the story. Giedion recounts an encounter with an architect who had worked on the Chicago fair half a century years earlier. Who was this elderly person? Was he or she one of those "lonely American voices [that] went unheard?" Why did he or she 
quote the pragmatist philosopher and psychologist William James? Archival research reveals lively historical details.

The call to lecture at Harvard first reached Giedion through his old friend Walter Gropius who had recently emigrated from Europe to head Harvard's school of design. In Europe, Gropius had founded and directed the Bauhaus, a short-lived but legendary school of design that Giedion had visited and published about.

Because Giedion was offered a position in poetry (which in this particular arrangement included art and architectural history), Gropius insisted that Giedion learn English and prepare his lectures. Towards this purpose, he sent Giedion a book on the history of architecture and urbanism that had recently been published, The Culture of Cities, by Lewis Mumford. ${ }^{30}$

Mumford's book chapter "The Triumph of Iron" could have interested Giedion. ${ }^{31}$ Years earlier, Giedion had published an entire book about architecture in iron..$^{32}$ Mumford offered an American perspective on building in iron, and he discussed Chicago's early skyscrapers, for example the Leiter Building. ${ }^{33}$ It is unclear, however, whether Giedion actually read "The Triumph of Iron."

With or without Mumford's historiography of the iron skyscrapers, Chicago was of immediate interest to Giedion because of a personal coincidence. His closest Bauhaus friend, László Moholy-Nagy, was trying to establish a "New Bauhaus" in the city and asked Giedion whether he accepted being listed as faculty at this new "American School of Design." ${ }^{34}$ Years later, Giedion spent his summertime and lectured there.

Back in 1938, when Giedion was contemplating to visit his friend in Chicago, he did not initially expect to study early skyscrapers. Instead, he marked interest in speaking with Frank Lloyd Wright who had established his first architectural company in the city in 1893. However, Moholy-Nagy responded with mixed feelings, encouraging Giedion to also consider Chicago's earlier "peasant architecture. ${ }^{135}$ With this advice in mind, Giedion decided to study the "anonymous architecture" that had been there in Chicago before Wright, hence, before 1893.

I already agree with most of your concerns. I, too, believe due to various reasons that there was outstanding anonymous architecture before Wright. Now, the task is to prove this [hypothesis] with conclusive examples. ${ }^{36}$

Interest in first-hand knowledge of Chicago's architecture of the 1880 s comes to bear in Giedion's letters repeatedly between November 1938 and early January 1939. ${ }^{37}$ Nevertheless, none of these letters calls this architecture Chicago school. ${ }^{38}$ Only a few days later, Giedion finally reached Chicago.

The first correspondence among Geidion's papers to make use of the term Chicago school is a short and probably hasty letter that he mailed at the end of January 
1939, upon returning to Harvard. The letter is critical for understanding what Giedion himself saw in his mind's eye when he read his own narrative of the Chicago school. The letter contains details about Giedion's encounter with the elderly architect who had worked some fifty years earlier on the Chicago fair, and who, in Giedion's presence, quoted William James from memory. This very same person, a certain Frank B. Long, told Giedion the history of the Chicago school with a personal touch that was very much appreciated.

\section{Dear Mr. Long:}

Upon returning from Chicago and New York your kind letter concerning the history of the firm of Holabird and Roche and the letter of Professor James, was on my desk. It was really charming that you found the time to send me these facts.

I very much enjoyed your personal touch in telling me the history of the Chicago school. Concerning your citation of Professor James, I should know precisely from which book it was taken. ${ }^{39}$

The details that we learn from this letter allow us to date Giedion's encounter with the Chicago architect whom he mentioned but did not name in Space, Time and Architecture. In addition, the letter also reveals this anonymous architect's identity as Frank Long, which already renders the event livelier. The next question is why Long never replied. Did the mailing go astray? The letter had been addressed to Holabird \& Root, a well-known company that had been founded back in the 1880 s, then as Holabird \& Roche. The mailman could not have mistaken the mailbox. Giedion met there with both John A. Holabird (father and son) and John W. Root. ${ }^{40}$ In March 1939, Giedion kept corresponding with Holabird and Root, yet, Long did no longer sign.

Who was this mysterious Frank Long who initially impressed Giedion, but later failed to keep in touch? An elderly person, he is unlikely to have been suddenly fired and to have burned his bridges with his employer. Maybe he could not answer because he fell sick. Maybe he passed away. Maybe this sad loss made Gidion decide to give Long a voice, although an anonymous one, in Space, Time and Architecture. If this were so, one could glimpse something very personal for Giedion. One could glimpse something he did not wish to make public. Nevertheless, when Giedion read his own lines, this encounter, and this loss is what he saw in his mind's eye.

Looking through obituaries from fall 1939, it is revealed that Long studied architecture in Urbana, Champaign, before starting to practice in Chicago at the time of the Chicago fair. ${ }^{41} \mathrm{He}$ was employed as architect with Holabird \& Roche and later became partner. Within the company, Long had close ties to the engineers. His specialty was the design of hotels that, with their all-same windows, helped define the facade de- 
signs of the Chicago school. Giedion later included several hotels and apartment buildings in his narrative of the Chicago school.

The fact that Frank Long quoted the philosopher William James sheds further light onto his mindset. Quoting James would seem a key move in a discussion that dealt with both the Chicago fair and the Chicago school. Fact is that James did not visit the Chicago fair in 1893 because he disapproved of it, as results from the quotation in question. In addition, James wrote a famous essay in 1904 titled "The Chicago School." The essay was published in the opening pages of the first print of the Psychological Bulletin ${ }^{42}$ which is a top tier scientific journal in psychology today.

But Long spoke about architecture and about 1893. He said that he had built one or more buildings for the Chicago fair, and he said that William James disapproved of the fair. These two statements only make sense together if Long disliked the work that he or his colleagues did at the fair. But what did he say about the history of the Chicago school that captured Giedion's mind?

Clearly, Long could not have said that the Chicago school started in 1893, at the Chicago fair. Giedion learned to oppose this view. As a local architect, Long must have remembered something else, something earlier, something that Giedion appreciated. A closer look at the historical context reveals a fascinating sequence of events.

A famous journalist, John Willis Abbot, wrote about the Chicago fair in 1893 and mocked, "The men who built the fair [...] were not selected to glorify the Chicago school of architecture, but were selected among the most eminent of their profession. ${ }^{143}$ These words are rabble-rousing. It can be inferred, that, following Abbot's perspective, the architects of the Chicago school were not among the most eminent of their profession in the country. Regardless of such interpretation, these lines instruct us that something must have been known as "Chicago school" prior to 1893. By 1893, the Chicago school must have been a matter of public debate.

In addition, Abbot's article also tells us that Chicago school and Chicago fair had broken apart by 1893. Abbot admitted that some Chicago architects had been selected to contribute to the fair, but he chose to also mock this architecture. He wrote that Adler \& Sullivan "planned the Transportation Building with its 'golden portal' which by the way was never golden." Such mockery makes only sense as a result of partisanship.

The schism between Chicago school and Chicago fair becomes most evident when other Midwestern architects who contributed to the fair are also considered. Next to Adler \& Sullivan, there was also Henry Van Brunt, a Kansas-based architect and scholar of evolutionism. Giedion's dramatic description of the fair is only a pale shadow compared to what Van Brunt portrayed in 1892 as "a vast phantasm of architecture, glittering with domes, towers, and banners, like a vision of Norumbega, which present- 
ly will fade and leave no trace behind. ${ }^{44}$ Van Brunt's goes on to tell that the fair does not well represent the achievements of American architecture.

It is not expected that this display, however successful it may prove in execution, should make a new revival or a new school in the architecture of our country. ${ }^{45}$ Probably, the largest $[\ldots]$ and the most conspicuous expressions of the present condition of architecture in this country will be looked for by foreign critics [not] on the grounds of the [fair]; but they will find it rather in the latest commercial, educational, and domestic structures in and near our largest cities. ${ }^{46}$

The fact that Van Brunt describes the fair as a vast phantasm that will not make a "school" in American architecture is symptomatic. Back in 1889, he had written a long article endorsing the work of his Midwestern and Chicago peers such as Adler \& Sullivan (Fig.1bc), Holabird \& Roche (Fig.2ab), Burnham \& Root (Fig.5ac), and William Le Baron Jenney (Fig.1a, Fig.2cd). ${ }^{47}$ Van Brunt posited that these architects formed "a school which may be recognized in history as the proper exponent of this marvelous civilization. ${ }^{48}$ In the "strenuous liberty of the West," ${ }^{49}$ the architects of this school developed bold design solutions "based upon science and invention." ${ }^{50}$ Adler \& Sullivan's Auditorium Building with its golden arches was one of Van Brunt's examples (Fig.1b, Fig.3a). ${ }^{51}$ Abbot's mockery is targeted exactly at these ideas: the Chicago school, an architecture of international merit, and Sullivan's arches. The reason is clear; Van Brunt criticized the fair on these grounds whereas Abbot wished to praise it.

Van Brunt was closely involved in the fair. In 1892, he had think twice before writing. For William James, everything was easier. As a philosopher, he did not build, and he did not go.

Long's part in this story is that of a young architect torn between Chicago school and Chicago fair. He did not remain neutral. Almost immediately after Giedion left the offices of Holabird \& Roche, Long mailed a letter with additional information on the company. Enclosed was also a copy of the correspondence of William James's, in which the Harvard philosopher said that he did not wish to visit the fair.

Forcefully siding with the Chicago school, Long also wrote Giedion that the early Chicago developments revolutionized the building industry not only in Chicago and America, but in the whole world.

The Tacoma Building [Fig.2b], completed in 1888, [...] and the decade in which it was designed brought forth the developments which revolutionized the building industry not only in Chicago and America but in the whole world, developments which made the modern skyscraper not only possible but inevitable. ${ }^{52}$ 
Space, Time and Architecture clearly borrows from Long's letter. Coming to speak about the Chicago school on page ten, Giedion wrote that the 1880 s generation turned Chicago's business center into a global center of architecture.

From 1880 to the time of the Columbian Exposition of 1893, the "Loop" area in Chicago (its business quarter, that is) was the center of architectural development not merely for the United States but for the whole world. ${ }^{53}$

Even Giedion's syntax "not merely [...] the United States, but [...] the whole world" bares similarities to Long's "not only [...] Chicago and America but [...] the whole world."

\section{The Scientific American Schools}

With its desire to unite art and science and represent America on a global stage, the Chicago school creatively engaged the minds of American educators already in the late 20th century. As new academic programs were founded all over the country, the question was what school of thought these programs would eventually come to embody. ${ }^{54}$

William Ware, Van Brunt's former office partner and an acquaintance of William James's,$^{55}$ is an important figure in this context. He founded both the oldest American program in architecture at Massachusetts Institute of Technology and the Columbia 'Teck.' The Teck's history gives insights into an old-boy group surrounding Van Brunt and Ware; and it also helps us rediscover how the Chicago school eventually became a textbook-case of architectural history in 1900.

Ware's drawing manual gives insight into the Teck's academic positioning. He held that the work of the architect lies "midway between that of the artist and that of the engineer. ${ }^{156}$ In the 1880 s, such positioning seemed appropriate and mainstream. As we have seen, the idea of a midway between art and science is also key to the Chicago school, and by no mere coincidence. When Ware wrote these lines, his former office partner Henry Van Brunt had already moved to Kansas to build on the railroad and write that a new school of architecture emerging in the West that united art and science. Such developments made Ware decide on an academic orientation for the Teck that was more technical.

The first professor to teach architectural history at this institution was A.D.F. Hamlin, Ware's former student from MIT. Hamlin might have been Ware's choice for the position not only because of personal acquaintance, but also because the younger architect very much lived the vision of a productive unison between art and science: He drew beautiful watercolors (Fig.4), but he was also willing to learn how to apply 
mathematics to the study of history. In an article published in 1900, Hamlin used statistics, applying them to a poll organized by an architectural magazine. ${ }^{57}$ This allowed him to ask what architectural style the general audience favored. ${ }^{58}$

A well-traveled professor, Hamlin became most famous for writing the first American textbook in the history of architecture, and in this context, he mentioned the Chicago school in five reprints $\left(1900,1902,1904,1906\right.$, and 1907). ${ }^{59}$

Hamlin's "Chicago school" is similar to Van Brunt's. It is described as a school of skyscrapers, brought into existence by the "untrammeled freedom of art in a land without traditions" and "marked by a more utilitarian and unconventional treatment with results which are often extremely bold and effective. ${ }^{16}$ In contrast, the "Eastern school" was more conventional and adhered to heavier decoration intended to please the eye.

Thomas Tallmadge was one of the many historians who deeply admired Hamlin. When, in 1908, Tallmadge wrote that the idea of the Chicago school had come from the East, he might have had Hamlin in mind. Tallmadge also recounted that many students used Hamlin's textbook of architectural history as a guide on their travels trough Europe. ${ }^{61}$

The relationship between Europe and America was one of Hamlin's most political concerns, and in this context, Giedion cited him. ${ }^{62}$ Hamlin's political agenda must have resonated with the European vanguard at this critical point when things did not look good back home: In 1938, the vanguard fled from Europe, and revivalism made a comeback; but in New York, a professor of architecture had warned against European revivalism already thirty years earlier.

Revivalism was soulless, so Hamlin wrote. Why then did so many American students wish to go and study in Europe where this style was taught? Was it not better if students traveled independently (Fig.4), for example "from New York to Buffalo and Chicago?" 63 True, after the Chicago fair, American architecture had split. There was "the line [...] of monumental composition and planning [...] of the Paris school," but America also developed its own, wholly independent "line [...] of scientific construction." ${ }^{14}$

The "American school," as Hamlin collectively called what students could expect to find in the U.S., would eventually come to prevail. He foresaw that it would eventually be the turn of the Europeans to cross the Atlantic in search of science and high-ranking education. ${ }^{65}$

When Giedion cited this document, Hamlin's vision of a scientific American architecture that attracted European students was still waiting to be fully implemented. Could the European emigrants Gropius, Ludwig Mies van der Rohe, and their peers help promote a scientific worldview that attracted Europeans such as Zevi (Fig.5b)? 


\section{Science in Demented Times}

Space, Time, and Architecture, the book title that Giedion chose for his Harvard publication of 1941, tells its own scientific story. The word pair space/time is reflective of Giedion's interest in the physics of space-time, first formulated in Switzerland by Albert Einstein and Hermann Minkowsky. ${ }^{66}$ On these premises, Giedion's 1941 title echoes Felix Auerbach's Space and Time, Matter and Energy. ${ }^{67}$

In this fascinating science book written for lay audiences in 1921, Auerbach made the concept of space-time and the theory of relativity more easily accessible to readers not trained in either contemporary physics or four-dimensional mathematics. He used Minkowsky's geometrical representation of space-time and Einstein's equation $e=m c^{2}$ to explain why space and time are best interpreted as space-time, and why matter is the same as energy. Giedion's title choice Space, Time and Architecture goes with Auerbach for the space/time word pair. "Matter and Energy" are contracted to "Architecture." When Giedion read the word "architecture" in Space, Time and Architecture, he might have privately taken the license to imagine it as a one-word expression for of Einstein's famous equation $e=m c^{2}$. Zevi later wrote Einstein and blamed Giedion. Einstein privately agreed. But the title Space, Time and Architecture, might just as well have symbolized something else, and again, something more dramatic that would remain unspeakable.

Auerbach died tragically in 1933, only five years before Giedion emigrated from Europe. Gropius and other fellow emigrants must have associated his name with both awe and fear. Following the publication of Space and Time, Matter and Energy, Auerbach commissioned Walter Gropius to design and build his house as a future-oriented "machine for living in. ${ }^{168}$ When artists met there, they could have spoken about Space and Time, Matter and Energy, and they could have seen Auerbach's portrait painted by the expressionist artist Edward Munch, famous for his artworks "Despair" and "The Scream." However, the Auerbach circle was short-lived due to political chaos. In 1933, when the Nazi party seized power over Germany, Auerbach and his wife committed suicide-or so it was recorded. The news might have frightened Gropius, who employed Giedion at Harvard. Giedion's wife, an art historian of German-Jewish descent, was in touch with the Auerbach circle, too. ${ }^{69}$

Auerbach left another, little recognized legacy. Only few years after Munch portrayed him, he embarked on a nightly balloon flight over Germany and made a peculiar observation. Looking down from the basket, he saw only few large cities, surrounded by many smaller towns, villages, and hamlets. A systematic thinker, Auerbach put this observation into numbers. ${ }^{70}$

The scientific result that Auerbach obtained was that the sizes of the cities in any given geographical area follow a predictable distribution. For example, if you know how many large cities there are, you can use Auerbach's formula to guess how many 
small towns, villages, and hamlets there must also be. Auerbach was surprised to notice that income follows the same type of distribution. Few people make big money; many make small money. Vilfredo Pareto, who had discovered this fact a decade earlier, illustrated it as a "pyramid" of income. ${ }^{71}$ Today, the distribution is named after Pareto, but it applies to many different fields of study.

In the U.S., Alfred Lotka used one of Auerbach's surveys of physics and counted how many times each author was cited in the bibliography. This quantitative evaluation made Lotka also discover a Pareto distribution (or, if you prefer, a ParetoAuerbach-Lotka distribution). ${ }^{72}$ Few authors earned many citations; many others earned few. Bibliometrics eventually emerged from Lotka's discovery as an entire new field of study.

In the 1930s at Harvard, George K. Zipf studied word frequencies and also discovered a Pareto distribution. He counted how many times each word was used in a given collection of texts. He found that there are few commonly used words and many rare ones. ${ }^{73}$ Zipf also looked at other data, such as the sizes of stars. There are few big stars and many small ones. Suddenly the term was coined Zipf's law.

Zipf unfortunately died after a sudden illness in 1950. However, his last article is also a beginning of something new: It was published in the first number of a newly founded magazine of the vanguard. In this article, Zipf advanced the argument that art history had to become a scientific and mathematical discipline, as envisioned by the Vienna school. Giedion, who had studied in Vienna, received a preprint from the editors; and markings reveal that he read it attentively. ${ }^{74}$ However, no evidence suggests that Giedion engaged in any serious attempt to apply this particular scientific perspective to the Chicago school. This is surprising, given that Space, Time, and Architecture in its entirety was meant to unite art and science.

\section{The Growth of a New Tradition}

The great architectural historian A.D.F. Hamlin and the scientists Auerbach, Lotka, and Zipf worked with statistics. Nevertheless, they did not specifically quantify the growth of new traditions, and neither did Giedion. Maybe, this lacuna should be finally filled.

The Growth of a New Tradition is the subtitle that Giedion chose for Space, Time and Architecture. The word "tradition" stems from the Latin trans-dare, literally "to pass down." Studying a tradition means studying information that has been passed down, or disseminated and received over historical time. Such research is likely to involve many records. The HathiTrust, a large network of university libraries, holds more than 100,000 books and periodicals that contain references to Chicago schools. Studying these records helps quantify and evaluate how the idea of the Chicago school was passed down, and how it branched, split, and diversified. 
The remaining part of this article deals with this quantitative evaluation. Along the lines, Giedion's role as part of this growing new tradition is revisited.

\section{Copies and Variants}

The term Chicago school is attested in the news as far back as 1850. In the wake of epidemics, Chicagoans established new schools of medicine. However, East Cost academics criticized these schools for being too practice oriented. Chicagoans did not concede. They responded that their "Chicago school" adapted theory to practice and public needs. The Chicago school was a midway between theory and practice.

Over time, this idea became the common ethos of many Chicago schools across architecture, social science, broadcasting, and art. Many later Chicago schools united theory and practice. For example, William James called the Chicago school of thought a "via media," ${ }^{75}$ or midway, between two great philosophies, transcendentalism and pragmatism. The fist of these two philosophies builds on abstract reasoning as exclusive source of insight. The latter celebrates human perception and feeling as the only thing that matters.

Although dealing with a different field of study, Giedion's words are uncannily close. In 1941, he wrote that the Chicago school of architecture "stood halfway between 'neutral' industrial construction and the human residence, with its inescapable associations of feeling. ${ }^{.76}$ Even the phrasing "halfway" seems a good match to the Latin "via media."

From a distant and detached perspective that lacks detail, the Chicago schools of James and Giedion resemble each other, and they also resemble other Chicago schools. For example, Robert E. Park, who studied under James at Harvard, eventually became recognized as a founding figure of the "Chicago school of sociology." In addition, there also exist Chicago schools of economics, law, symbolic interactionism, and many more that have been passed on from generation to generation. Most of these schools share a common ethos. Because of this congruence, most Chicago schools can be interpreted as copies of each other.

Of course, one could decide to add in more detail. People have given slightly different names do slightly different schools. For example, some authors who focused on the work of Park spoke specifically of a "Chicago School of Park." ${ }^{177}$ One could decide to say that the change from "Chicago school of sociology" to "Chicago school of Park" really creates two distinct variants.

Following this observation, Chicago schools are more or less exact copies of each other. Exact reproduction occurs when ideas are perpetuated without change. In contrast, approximate reproduction occurs when change is involved. Exact and approximate reproduction occurs in parallel, as part of the same process. In the life sci- 
ences, approximate reproduction is also known as variation, and the process of exact and approximate reproduction is also known as variation-selection process.

In our case, the theory behind variation-selection processes allows us to predict how Chicago schools spread, and how they are distributed. Even before collecting data, one can guess how often each school (or each arbitrary group of schools) was mentioned in the public media at any given point in time. Under commonly observed conditions, a Pareto distribution emerges as a natural result of this process (or if you wish, a Pareto-Auerbach-Lotka-Zipf distribution). The Chicago schools of social science are the largest group of Chicago school today. Empirical data on these schools confirms the prediction (Fig.6). ${ }^{78}$

Fig. 6 Large-scale dissemination. Chicago schools of sociology and related fields. The records that mention these schools are put into groups of schools. The prevalence of each group is estimated using variation-selection processes (quasispecies equation). The observed historical data confirm the prediction. Simulation mechanism from Bertels et al. 2017. Methodology described in previous publication.

A Distributions resulting from variation-selection processes over time. B Distributions from simulation (left), and from empirical data (right). (Data: Chicaog school corpus.)

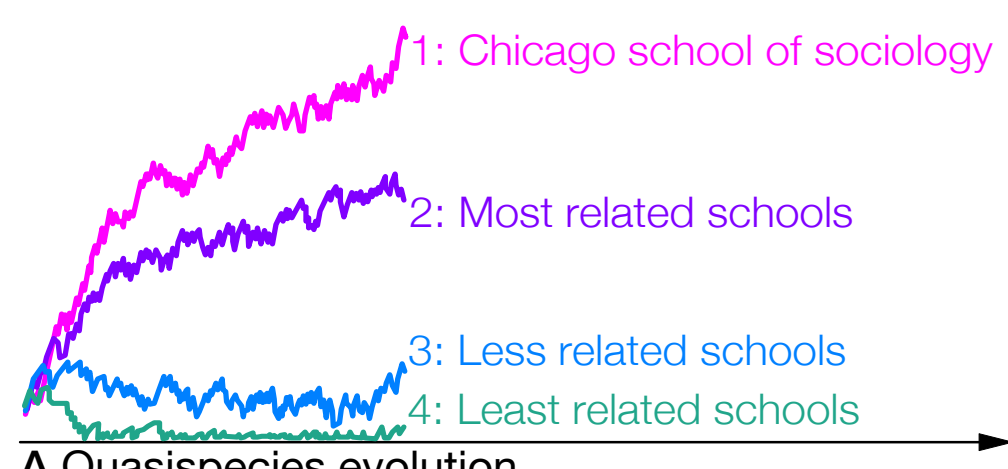

A Quasispecies evolution

flow simulated
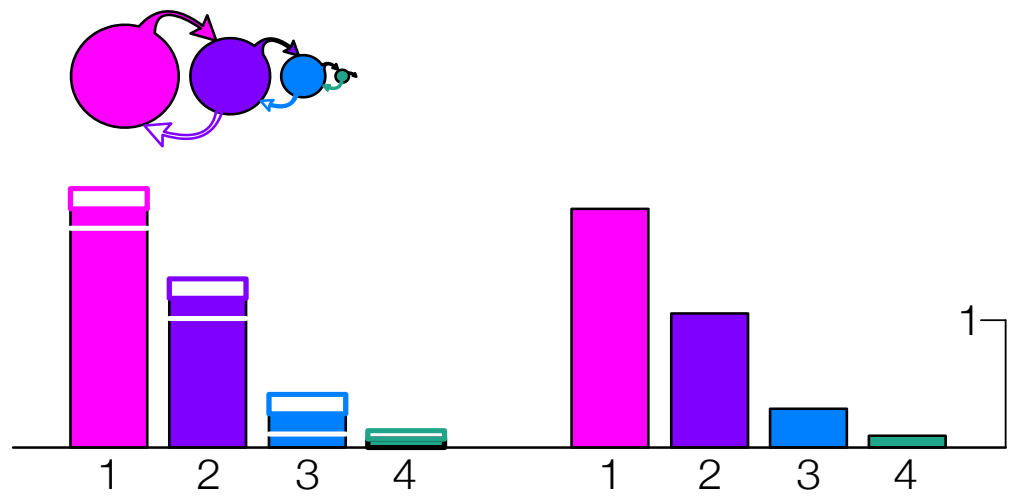

B Distribution of Chicago schools of sociology (Left: simulations. Right: empirical, $y=1 \mathrm{~K}$ references) 


\section{Pushing the Door Open to Something New}

Years after writing about the Chicago school, and years after reading Zipf's article, Giedion claimed in one of his letters that he pushed the door open to something new. He was not alone in entertaining such hopes. Indeed, "pushing the door open to something new" is a common expression. Many try. Scholars often engage in desperate searches for original contributions. If one departs from existing knowledge only to rediscover something old, what's the point of a scholar's work? The same urge for novelty pushes artists to think.

Modern art is occasionally so new that it is shocking to the public. The Vienna school of art history developed a whole art theory based on the idea of novelty. ${ }^{79}$ But shock and novelty are relative. At first, furor attracts audiences. But then, the interest ebbs out. Indifference is being built up.

In the life sciences, this process is called habituation. The word "habituation" is related to the simpler word "habit." Indifference is a type of habit because it is developed over repeated encounters with an idea, and, once established, it comes without much conscious consideration. The sensory organs keep sending all stimuli they receive to the brain, but the brain learns to detect, filter out, and become indifferent or, if you wish, 'immune' to superfluous information.

If we use mathematics to model the interplay between novelty and habituation, Lotka makes another comeback. We receive a system of differential equations originally formulated by him and today widely known as Lotka-Volterra equations. The equations predict wavelike wobbling. In our case, waves of fashion come, go, and return: First, a new fashion spreads; then disinterest spreads; then disinterest is forgotten; and finally, in absence of disinterest, the fashion has a chance to make a comeback.

The Chicago school of architecture in the second part of the 20the century was one such example. Five waves of interest followed upon each other's heels. Three of these waves coincide with museum exhibitions held by the Museum of Contemporary Art and by the Art Institute of Chicago. An informal discussion with John Zukowsky who curated the two exhibitions held at the Art Institute reveals that he was aware of such cycles of public interest and made the museum exhibitions coincide with them. But the equations also predict waves of interest in absence of exhibitions. (Fig.7AB)

\section{Diversification and Growth}

Modeling cycles of novelty and habituation with Lotka-Volterra equations also allows for important predictions with respect to cultural diversification. From the previous section, we know that ideas that become commonplace turn people indifferent. However, this does not mean that people become indifferent to life in general. ${ }^{80}$ On these premises, indifference chases people away from ideas that they know, giving new ideas a chance to spread..$^{81}$ 
Fig.7 Large-scale reception. Habituation and sensitization explain waves of fashion, periods of formation, diversity thresholds, and collective rise to fame.

A Media activity and habituation lead to waves of fashion as modeled with Lotka-Volterra equations. B Waves of fashion found in the Chicago school of architecture. Museum exhibitions ride the waves. (Chicago school corpus, 105K perodicals and books, $y=100$ references) $\mathrm{C}$ Habituation, discrimination and sensitization lead to a double-phased evolution with a diversity threshold between the two phases, individual spikes on the left and collective rise on the right. During fromation, ideas do not lie dormant, but diversity. D Historical data on the Chicago school at large confirm the predictions. The peak on the left is dominated by one school. The rise on the right is a consequence of collective breakthrough. (Data: google Books, y=1/10M words)

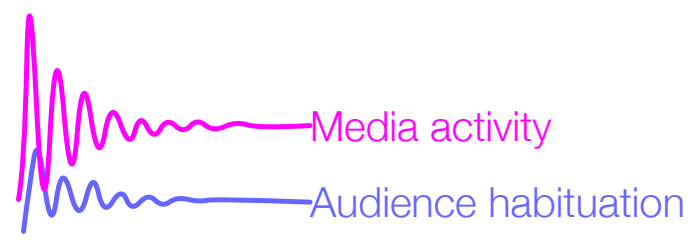

A Habituation cycles
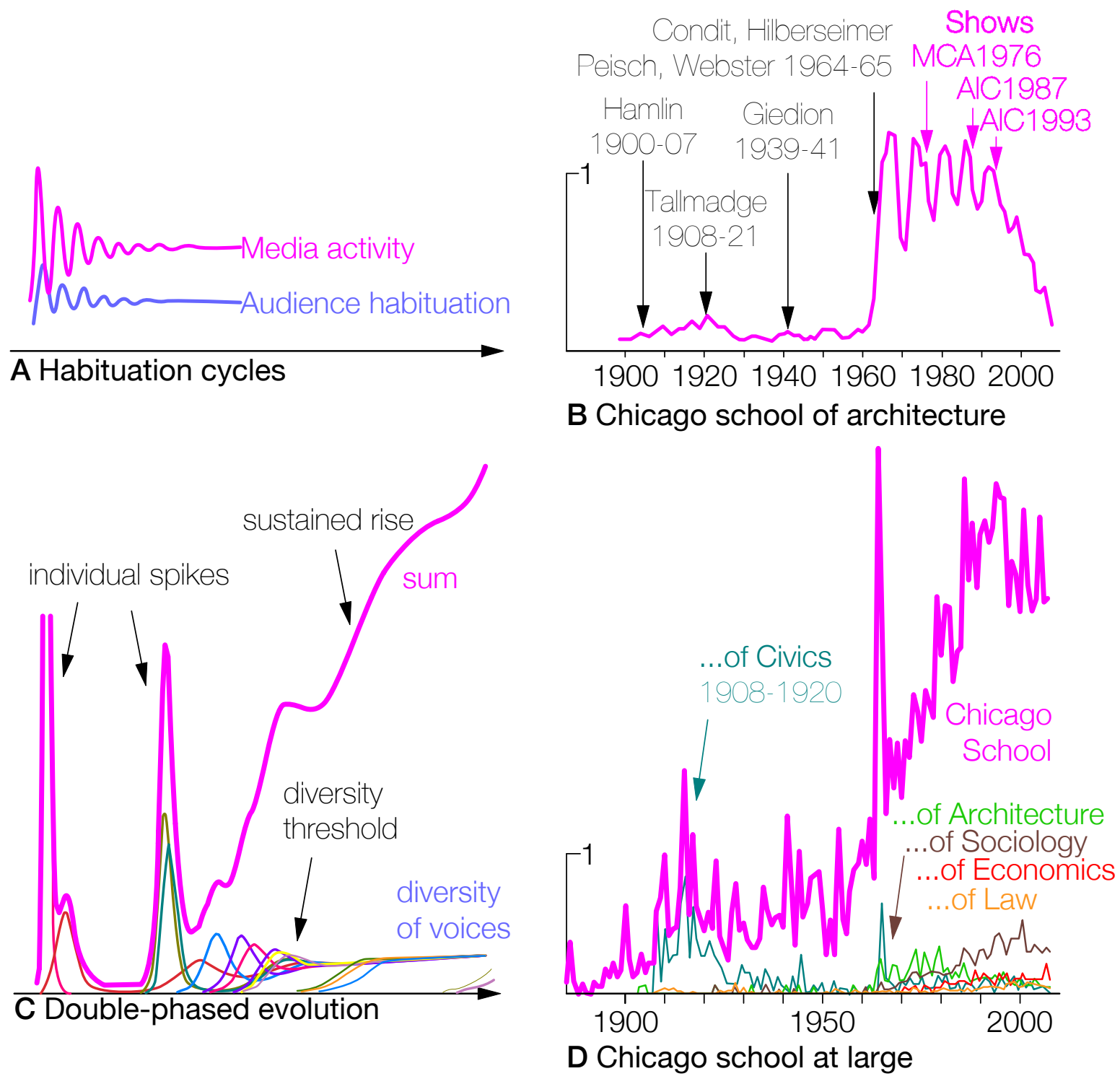
This process leaves room for multiple cultures to co-exist. Over time, new ideas, and new types of indifference are accumulated. Thus, strong ability to become indifferent (in technical terms, strong habituation) means high diversification but little overall growth. These predictions can be tested against data (Fig.8AB).

Take the example of the Chicago school at large. From 1850 to 1950, many authors pushed the door open to new Chicago schools. The Chicago school diversified to win over audiences across social science, architecture, art, and entertainment. Nevertheless, there was little overall growth. None of these schools found growing public interest over extended periods of time. People became indifferent.

With so many Chicago schools coexisting side-by-side a new question arises. Let us assume that new Chicago schools may re-establish interest in any old Chicago school. After all, if you find interest in a new Chicago school, this may also raise your appreciation of other Chicago schools. In technical terms, this phenomenon is called sensitization. Habituation and sensitization are the two most common processes of homeostatic regulation, which the brain uses to filter incoming information.

If we change Lotka's equations to take this phenomenon into account, a new, slightly more complex system of equations emerges. Similar to Lotka's equations, this newer mathematics also happens to be a well-studied textbook-case of life science. ${ }^{82}$

Following the new equations, one can predict that there is an initial period of diversification followed by a subsequent period of growth. Once a certain diversity threshold is reached, people regain interest in old ideas (i.e. sensitization disrupts habituation) and the equations accommodate steady growth. Intuitively, the reason is that cultural diversity works against indifference. It is easy to become indifferent to one isolated idea, but, to a diverse culture, it is more difficult. The history of the Chicago school at large serves as an empirical test (Fig.7CD). Beginning with the 1960s, the Chicago school grew steadily, which confirms the prediction.

A more detailed analysis of the equations reveals one further prediction. During the period of growth, sensitization disrupts habituation. This also means that diversification fails. ${ }^{83}$ The fastest growing Chicago schools come to predominate. In consequence, growth reduces diversity. These dynamics are confirmed for the Chicago school in Figure 8AB.

Finally, the results obtained through theory and mathematical prediction can also be tested through scholarly interpretation of historical material. The mathematical model predicts that Chicago schools were most diverse in the 1960s-and this is when $\mathrm{H}$. Allen Brooks criticized that there were too many different Chicago schools. The historian's perception matches the prediction obtained from the causal model.

In the 21st century, the model predicts less diversity among Chicago schools. This prediction holds as well. Many people know the Chicago school of sociology, but the Chicago school of architecture lost out. If one searches for Chicago schools in ar- 
chitectural periodicals in the 21st century, one is more likely to find sociology, economics, or law. The Chicago school of architecture finds little attention even in architectural magazines.

\section{From the Chicago School to Science at Large}

This present article followed Sigfried Giedion from Switzerland to Chicago where he met an elderly architect, Frank Long, who told him the history of the Chicago school with a personal touch that he "very much enjoyed." Long had moved to Chicago towards the end of the city's early construction boom, he worked on the Chicago fair as a young practitioner, and he read the pragmatist philosopher William James.

The oral history that Frank Long decided to pass down to Giedion should not be neglected. Long witnessed the history and achievements of the Chicago school from the late 1880 s to 1938 . He had first-hand knowledge of some of the early skyscrapers, and he also took position in the schism between Chicago school and Chicago fair. An old man, Long passed away shortly after meeting Giedion, but Giedion decided to give him a voice, although an anonymous one, in Space, Time and Architecture.

Historians such as Giedion should not be expected to gain all their knowledge from printed sources. Some information is passed on from generation to generation. The word "tradition" literally means to pass on.

The encounter between Long and Giedion sheds new light on events that lie far in the past. But this article also went beyond the reconstruction of unique historical events; it evaluated the interplay between entire groups of authors and audiences that pass down ideas from generation to generation. Following this evaluation, the Chicago school underwent a double-phased evolution. The first century (1850-1950) is a period of formation during which the idea of the Chicago school diversified. New and newer schools contributed to the accumulation of cultural diversity until a joint breakthrough was achieved. After breakthrough, Chicago schools began to grow, and they kept growing. Giedion's publication was a turning point in this long and complex process of diversification and growth.

When Giedion reached Chicago in 1939, he had already acquired a leading position among modernist historians, architects, artists, and designers. This position allowed him to impose himself against normative voices such as the NCARB without recurring to pedantry. Exactly these qualities were beneficial for the Chicago schools at their tipping point to joint breakthrough. Would Giedion have played the pedantic scholar insisting on the validity of his sources and explaining that he had only continued on a path already broken by Henry Van Brunt and A.D.F. Hamlin half a century earlier, his work might not have inspired the same sense of novelty that enriched the horizons of his contemporaries and helped the Chicago schools rise to fame together. 
Ironically, successful diversification is followed by growth, which, in turn, reduces diversity. During this process, the Chicago school of architecture has lost out. Giedion's Chicago school, once an ardently debated idea, has become a memory of the past.

Of course, the Chicago school at large will always remain a grand piece of history. In 1900, A.D.F. Hamlin rendered the Chicago school a textbook-case of architectural history. In 1938, Giedion rediscovered Hamlin's school; and Space, Time and Architecture became something of a textbook of architecture, as well. In turn, Zevi, Tafuri, Hitchcock, and others followed Giedion. They wrote surveys of architecture and urbanism. And the Chicago school also became a textbook-case of social science, which makes it well known today. Already William James's 1904 article "The Chicago School" was printed on the first pages of a scientific journal in psychology that has meanwhile become a top tier periodical with a high impact factor.

In addition, this present article also turns the Chicago school into a textbookcase of life science. Without anyone noticing, the history of the Chicago school is already printed in many textbooks of applied mathematics:

If one juxtaposes, on one side, the new theory of cultural diversification proposed in this article and tested against quantitative data on Chicago schools, with, on the other side, much older theories of biological evolution printed long ago in textbooks of life science,$^{84}$ the mathematics remains the same. But how is it possible that cultural and biological life undergo similar processes?

In both cases, the benefits that can be reaped from diversification are the driving factor behind the evolution of self-regulation. If the benefits of diversification are high enough, the system of self-regulation described above is likely to evolve naturally. $\mathrm{Na}$ ture is sparing when it comes to inventing new processes and new types of evolution. The same principles apply again and again to stunning effect. The role of the researcher is to rediscover known processes in new contexts.

The readers of this article may be part of such rediscovery. The theory formulated in this article has meanwhile ${ }^{85}$ proved useful in the evaluation of other new traditions that are larger and even more significant than the Chicago school. For example, the theory diversification developed here applies to "science" at large (Fig.8C). Where the Chicago school has gone through one cycle of diversification and growth over the last century, Science has gone through three such cycles over the last three centuries.

When you look at the historical data on science collected from millions of books, you see the same picture already discussed for the Chicago school. Periods of diversification and growth follow each other in a cyclic pattern: Initial diversification is followed by growth, followed by diversification, followed by growth, followed by diversification, etc. This cyclic process becomes visible as growth and reform. 
Fig.8 Growth and stagnation as a cycles of diversification. Habituation supports diversification but inhibits growth. Diversification disrupts habituation and allows for growth. Growth reduces diversity and leads to the return of habituation. These predictions are confirmed by measuring growth and Simpson's diversity index for Chicago schools of social science and for science branches. Growth and diversity index move against each other. Diversity index stays between thresholds.

A Diversity and growth delimit each other. B Diversity in Chicago schools of social science. C Science grows, diversity declines; then, growth stops, and diversity rebounds to threshold. Diversity index is computed from science branches. (Data: google Books)

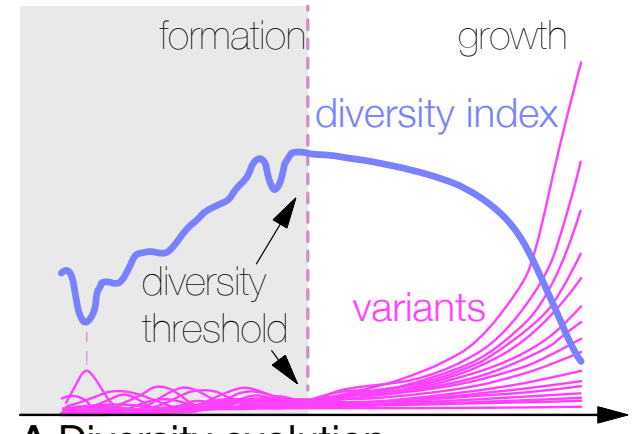

A Diversity evolution

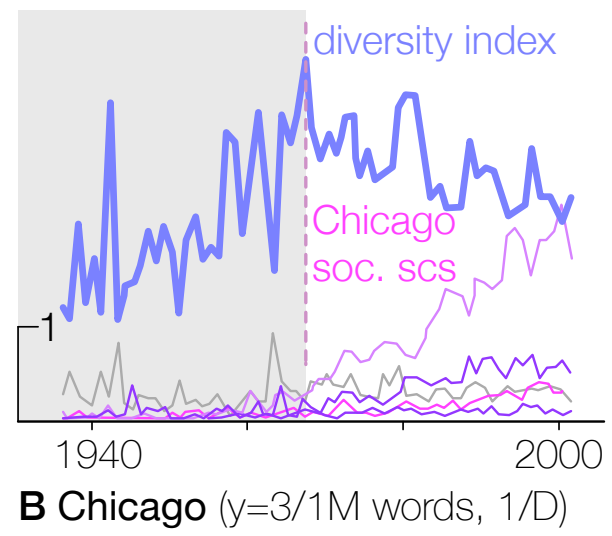

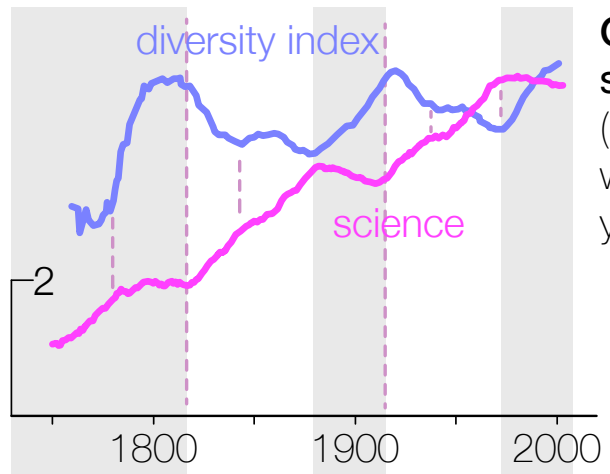

C Science and science branches. (above: $y=1 / 10 \mathrm{~K}$ words; 1/D; below: $y=1 / 100 K$ words)

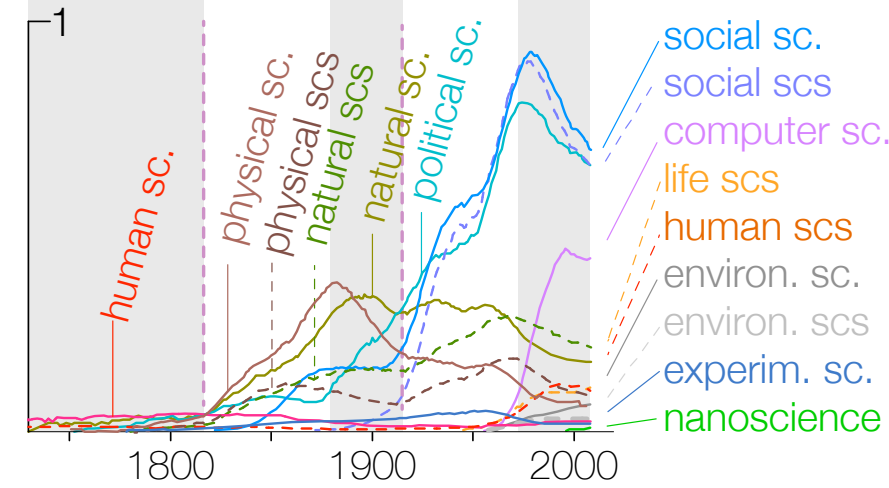

The researcher's ability to quantify diversification and growth and understand the relationship between them may turn out to be of great relevance in present and future. Just now, as you read this text, ideas spread around the world, authors and audiences habituate to novelty, and new traditions diversify, grow, or decay. Cultural life does not need to re-invent the same processes of diversification de novo. This also means that researchers can understand recurring processes and help people coordinate their efforts on a large scale.

Ultimately, I hope that the theory of diversification will be a contribution to the study of those large-scale problems that people have a hard time addressing because they require large-scale cooperation. These problems include urban and social segregation, awareness of the importance of healthy environment and biodiversity, as well 
issues faced in containing epidemics. (It may be no coincidence that the Chicago school is first attested in the wake of Cholera epidemics. The idea of a school was a cultural response to a collective problem.) All of these problems have in common that they are somehow related to urbanization, and they cannot be solved unless people find a cultural basis to cooperate.

\section{Bibliography and Notes}

Dan Costa Baciu. "Cultural Life: Theory and Emprical Testing" OSF Preprints (May 2020). DOI: 10.31219/osf.io/ad9fu [Summarizes and discusses theory and testing. Shows new testing on Science and University of California.]

Dan Costa Baciu. "Chicago Schools: Authors, Audiences, and History." Prometheus 2 (2019), p. 20-43. [Introduces the idea of entropic processes in human culture. Makes the connection between Shannon's definition of communication and negative entropy via variation-selection processes. Gives mathematics and testing with empirical data on the Chicago school.]

Dan Costa Baciu. "From Everything Called Chicago School towards the Theory of Varieties." Doctoral dissertation, Illinois Institute of Technology, April 2018. [Develops the theory of varieties as a theory of dissemination and reception with quasispecies and Lotka-Volterra equations, gives testing results, explains methods.]

Dan Costa Baciu. "The Chicago School: Evolving Systems of Value." Report for the Advanced Collaborative Support Project 06.2016-03.2017 at the Hathi Trust Research Center, October 2017. [Develops the theory of dissemination with the quasispecies equation; tests the theoy; and explains some methods and applications.]

Dan Costa Baciu. "Sigfried Giedion: Historiography and History of Reception on a Global Stage." Ar(t)chitecture, Haifa: Technion Israel Institute of Technology 2016, p. 40-52. [Shows an application of the theory.]

\footnotetext{
${ }^{1}$ Heinrich Wölfflin, 1864-1945.

${ }^{2}$ In his chapter "Towards Pure Froms," Giedion juxtaposed the Leiter Building with Le Corbusier's Maison Clarté, the Reliance Building with Ludwig Mies van der Rohe's 1921 project for a glass tower, and the Sullivan Center (initially called Carson, Pirie, Scott and Company Department Store) with Walter Gropius' 1923 project for the Tribune Tower Competition Compare to Fig.3a and $b$.

${ }^{3}$ This title can be found, for example in Giedion's letter to Moholy-Nagy from December 19, 1938. GTA Archive, 43-K-1938-12-19-6.

${ }^{4}$ New York University Bureau of Public Information, press release, spring 1939, GTA Archive, 43-T-13-1-5-2-2, p.3.

${ }^{5}$ NCARB letter to Sigfried Giedion, July 1939. Cited from: Dan Costa Baciu, "Sigfried Giedion: Historiography and History of Reception on a Global Stage," editors Iris Aravot and Dana Margalith $\operatorname{Ar}(\mathrm{t})$ chitecture, Haifa: Technion Faculty of Architecture and Urban Planning 2016, 41.
} 
${ }^{6}$ Sigfried Giedion, Space, Time and Architecture, Cambridge, MA: Harvard University Press, 1941. Cited from, third edition, 1954, 389.

${ }^{7}$ Sigfried Giedion, "The Danger and Advantages of Luxury," Focus 3 (1939), GTA Archive 43-T15-1939-1.

${ }^{8}$ Sigfried Giedion, lecturer, "America influences Europe: The Chicago School and Frank Lloyd Wright," Charles Eliot Norton Lectures, Harvard University, 1939, GTA Archive, 43-T-13-7-1-82.

${ }^{9}$ New York University Bureau of Public Information, press release, spring 1939, GTA Archive, 43-T-13-1-5-2-2.

${ }^{10}$ Sigfried Giedion, Space Time and Architecture, Cambridge, MA: Harvard University Press, 1941.

${ }^{11}$ Sigfried Giedion, letter to Holabird \& Root, March 15, 1939. GTA Archives, 43-K-1939-03-15(G) $1 / 4$.

12 Masami Takayama, "Good Buildings, Cheap," Interview with John A. Holabird, Proecess 35, (1983), 25.

${ }^{13}$ Bruno Zevi, "Messaggio al Congrès International d'Architecture Moderne. Della Cultura Architettonica," Metron, 31 (1949), 10.

${ }^{14}$ Bruno Zevi, "La Scuola di Chicago," Storia dell'Architettura Moderna, 1950, 392. "A Chicago non si tratta solo di grandi individui, ma del riconosciuto superamento del binomio artetecnica."

${ }^{15}$ Bruno Zevi, "Messaggio al Congrès International d'Architecture Moderne. Della Cultura Architettonica," Metron, 31 (1949), 10.

${ }^{16}$ Carl W. Condit, The Rise of the Skyscraper, Chicago: University of Chicago Press, 1952.

${ }^{17}$ Carl W. Condit, The Chicago School of Architecture: A History of Commercial and Public Building in Chicago 1875-1925, Chicago: University of Chicago Press, 1964.

${ }^{18}$ D[ebra] M[ankoff], interview with Carl W. Condit, Carl W. Condit Papers, Northwestern University Archives. Cited from: Dan C. Baciu, "Sigfried Giedion's Chicago School," research plan, Swiss National Science Foundation, Proj. Nr. 174883.

${ }^{19}$ Colin Rowe, "Chicago Frame," in The Mathematics of the Ideal Villa and Other Essays, Cambridge, MA: The MIT Press, 1976.

${ }^{20}$ Ludwig Hilberseimer, Contemporary Architecture: Its Roots and Trends, Chicago: Paul Theobald, 1964.

${ }^{21}$ Manfredo Tafuri, "The Disenchanted Mountain: The Skyscraper and the City," in: The American City from the Civil War to the New Deal, Cambridge, MA: The MIT Press, 1983. Originally published, 1973.

${ }^{22}$ Henry Russell Hitchcock, Architecture: Nineteenth and Twentieth Centuries, Baltimore: Penguin Books, 1958.

${ }^{23}$ David Van Zanten, Ashley Elizabeth Dunn, Leslie Coburn, Chicago Architecture on the International Stage 1900-1925, Evanston: Northwestern University Press, 2013, 38.

Mark L. Peisch, The Chicago School of Architecture: Early Followers of Sullivan and Wright. London: Phaidon Press, 1964.

Debra N. Mankoff, "Thomas Eddy Tallmadge. Historian for the 'Chicago School,"” dissertation, Northwestern University, Evanston 1978.

H. Allen Brooks, “'Chicago School' Metamorphosis of a Term," Journal of the Society of Architectural Historians, 25, 2 (May 1966), 115.

${ }^{24}$ Mark L. Peisch, The Chicago School of Architecture: Early Followers of Sullivan and Wright. London: Phaidon Press, 1964. 3. 
${ }^{25} \mathrm{H}$. Allen Brooks, "'Chicago School' Metamorphosis of a Term," Journal of the Society of Architectural Historians, 25, 2 (May 1966), 115.

J. Carson Webster, editor, "The Other Panelists: Sir John Summerson [moderator], HenryRussell Hitchcock, H. Allen Brooks [panelists],"Prairie School Review 9, 2 (Second Quarter 1972), 16-22.

${ }^{26}$ Robert Bruegmann, "The Marquette Building and the Myth of the Chicago School," Threshold, 1991. [Reprinted in Charles Waldheim and Katerina Ruedi Ray, Chicago Architecture Histories, Revisions, Alternatives. Chicago: University of Chicago Press, 2005, 15-29.]

27 Joanna Merwood-Salisbury, Chicago 1890: The Skyscraper and the Modern City, Chicago: University of Chicago Press, 2009.

${ }^{28}$ Thomas Eddy Tallmadge, "The 'Chicago School,'” The Architectural Review 15.4 (1908), 69$74,69$.

${ }^{29}$ Sigfried Giedion, Space Time and Architecture, Boston: Harvard University Press, 1941. 392.

${ }^{30}$ Walter Gropius, letter to Sigfried Giedion, April 13, 1938. GTA Archives: 43-K-1938-04-12.

${ }^{31}$ Sigfried Giedion, letter to Walter Gropius, May 14, 1938. GTA Archives: 43-K-1938-05-14(G).

${ }^{32}$ Sigfried Giedion, Bauen in Frankreich, Eisen, Eisenbeton. Leipzig: Kinkhardt \& Biermann, 1928.

${ }^{33}$ Lewis Mumford, "The Triumph of Iron," in The Culture of Cities, 1938. This book is the second volume in the four-volume series "Renewal of Life." Giedion had already partially read the first volume Technics and Civilisation. In the context of Giedion's research on the Chicago school, it is important to notice that Mumford did not use the term Chicago school in his chapter "The Triumph of Iron." It may also be important to notice that Gropius wrote to Giedion that, from Harvard, Chicago was almost as far away as Europe. Source: Walter Gropius, letter to Sigfried Giedion, April 13, 1938, 2. GTA Archives, 43-K-1938-04-13.

${ }^{34}$ L. Moholy-Nagy, letter to Sigfried Giedion, April 27, 1938. GTA Archives, 43-K-1938-0427:1/2.

${ }^{35}$ [Frank Lloyd Wright] was not very enchanted to hear that we opened a New Bauhaus and I remember at the beginning our activities he refused to see me. [... ${ }^{35}$ I think that a tour through the Middle West would make it clear to you that a very genial peasant architecture was developed here in the forties and sixties of the past century, [...] which we know as significant of this type under the name of Wright. László Moholy-Nagy letter to Sigfried Giedion, October 24, 1938. GTA Archives, 43-K-1938-10-24:1/2

${ }^{36}$ Sigfried Giedion, letter to László Moholy-Nagy, November 2, 1938. GTA Archives, 43-K1938-11-2.

${ }^{37}$ Sigfried Giedion, letter to László Moholy-Nagy, December 19, 1938. GTA Archives, 43-K1938-12-19.

${ }^{38}$ Nor any other letter dating from 1938.

${ }^{39}$ Sigfried Giedion, letter to Frank B. Long, January 30, 1939. GTA Archives, 43-K-1939-01-30.

${ }^{40}$ Sigfried Giedion, letter to John W. Root, March 15, 1939. GTA Archives 43-K-1939-0315(G):4.

${ }^{41}$ Frank B Long, obituary, New York Times, September 30, 1939.

${ }^{42}$ William James, "The Chicago School," Psychological Bulletin 1, (1904), 1-5.

${ }^{43}$ John Willis Abbot, "The Makers of the Fair," The Outlook 48, (November 1893), 18.

${ }^{44}$ Henry Van Brunt, "Architecture at the World's Columbian Exposition," The Century Magazine 6, 1982, 86

${ }^{45}$ Henry Van Brunt, "Architecture at the World's Columbian Exposition," The Century Magazine 6, 1982, 88. 
${ }^{46}$ Henry Van Brunt, "Architecture at the World's Columbian Exposition," The Century Magazine 6, 1982, 86

${ }^{47}$ Henry Van Brunt, "Architecture in the West," The Atlantic 64, (1889), 772-784.

${ }^{48}$ Henry Van Brunt, "Architecture in the West," The Atlantic 64, (1889), 777.

${ }^{49}$ Henry Van Brunt, "Architecture in the West," The Atlantic 64, (1889), 777.

${ }^{50}$ Henry Van Brunt, "Architecture in the West," The Atlantic 64, (1889), 779, 781.

${ }^{51}$ With its golden arch with gold shimmering light bulbs over the orchestra, the Auditorium may well have been a precursor to the golden portal of the Transportation Building.

${ }^{52}$ Frank B. Long, letter to Sigfried Giedion, Jan 19, 1939. GTA Archives: 43-K-1939-01-19.

${ }^{53}$ Sigfried Giedion, Space Time and Architecture, Cambridge, MA: Harvard University Press, $1941,10$.

${ }^{54}$ Already in 1893, an educational program was established in the spirit of the Chicago school. The Art Institute of Chicago joined forces with the newly founded Armour Institute of Technology: The Art Institute offered design, Armour introduced mathematics and material science, and their unison was formally called the Chicago School of Architecture. The main figure that first initiated this educational program was no less than the interior designer whom Adler \& Sullivan commissioned to decorate the Auditorium Building. The addition of mathematics in 1893 helped materialize Van Brunt's vision of 1889.

However, the Chicago School of Architecture changed its focus over the course of time. Eventually, Ludwig Mies van der Rohe, one of Giedion's Bauhaus friends, was called to reform this program, once again strengthening its technical orientation.

${ }^{55}$ The acquaintance can be inferred from the letters of William James in which an architect William Ware is mentioned.

${ }^{56}$ William R. Ware, The Instruction in Architectural Drawing at the School of Architecture. New York: Columbia University, 1896. [First printed in: The School of Mines Quarterly 17.1 (November 1895)]

${ }^{57}$ Hamlin, Alfred Dwight Foster. "The Ten Most Beautiful Buildings: A Discussion of the Vote by A.D.F. Hamlin," The Brochure Series of Architectural Illustration 1, (January 1900), 5-13.

${ }^{58}$ Based on the statistical evidence, he concluded that multiple styles coexisted.

${ }^{59}$ Alfred Dwight Foster Hamlin, A Text-book of the History of Architecture, New York: Longmans Green and Co, 1895, reprints Oct. 1900, Oct. 1902, Sept. 1904, June 1906, Nov. 1907. ${ }^{60}$ Alfred Dwight Foster Hamlin, A Text-book of the History of Architecture, New York: Longmans Green and Co, 1895, reprint Oct. 1900, 397.

${ }^{61}$ Thomas Eddy Tallmadge, The Story of Architecture in America. New York: W. W. Norton \& Co, 1927.

62 The missing three initials rendered the source somewhat ambiguous to contemporary readers. A.D.F. Hamlin had a son, Talbot Hamlin, who also became an architectural historian at Columbia University. In 1934, the younger Hamlin started the Avery Index for Architectural Periodicals. Giedion's contemporaries could well have taken the reference to this "Professor Hamlin" for a reference the younger professor. Shortly upon Giedion's visit to Chicago, he and Talbot Hamlin met; they became friends; and their wives met, too. The younger Hamlin would have been the more likely candidate to earn a citation from Giedion.

${ }^{63}$ A.D.F. Hamlin, "The Influence of the Ecole des Beaux Arts on Our Architectural Education," Architectural Record, April 23 (1908), 243.

${ }^{64}$ A.D.F. Hamlin, "The Influence of the Ecole des Beaux Arts on Our Architectural Education," Architectural Record, April 23 (1908), 244. 
${ }^{65}$ A.D.F. Hamlin, "The Influence of the Ecole des Beaux Arts on Our Architectural Education," Architectural Record, April 23 (1908), 241-247.

${ }^{66}$ Sigfried Giedion, letter to Herbert Bayer, 1940. GTA Archives, 43-K-1940(G):1/4.

${ }^{67}$ Felix Auerbach, "Raum und Zeit, Materie und Energie: Eine Einführung in die Relativitätstheorie." Ordentliche Veröffentlichungen der Pädagogischen Literatur-Gesellschaft Neue Bahnen, [Leipzig] 1921.

${ }^{68}$ Walter Gropius, "Typenserienhaus von Walter Gropius," presentation, 1923. Cited from: Barbara Happe, Martin S. Fischer, Das Haus Auerbach von Walter Gropius mit Adolf Meyer. Tübingen: Ernst Wasmuth Verlag, 2003, 13.

${ }^{69}$ As can be concluded based on direct correspondence.

${ }^{70}$ Felix Auerbach, "Das Gesetz der Bevölkerungskonzentration," Petermanns Geographische Mitteilungen, 59, 1913, 73-76.

${ }^{71}$ Vilfredo Pareto, Cours d'Economie Politique, Lausanne: F.Rouge, 1896.

${ }^{72}$ Alfred J.Lotka, "The frequency distribution of scientific productivity," Journal of the Washington Academy of Sciences 16, (1926), 317-323.

${ }^{73}$ George K. Zipf, The Psycho-Biology of Language, Cambridge, MA: The MIT Press, 1965.

${ }^{74}$ Martin James, Harry Holtzman, letter to Sigfried Giedion, GTA Archives, 43-K-1949-12-30. George K. Zipf, "Interrelations Art, Architecture, Engineering," draft for article is attached to the letter.

${ }^{75}$ William James, "The Chicago School," Psychological Bulletin 1, (1904), 1.

${ }^{76}$ Sigfried Giedion, Space Time and Architecture, Cambridge, MA: Harvard University Press, 1941, 26.

${ }^{77}$ Taken together, there are Chicago schools in: different fields of study, for example architecture, philosophy, social science; schools in different disciplines, for example sociology, economics, law; cross-disciplinary schools, for example urban sociology; schools that are named after specific research directions, for example symbolic interactionism; schools that are named in honor of great figures; schools that deal with the city or the suburbs; schools in art, literature, and broadcasting; schools that many people believe in and schools that are the construct of novels.

${ }^{78} \mathrm{~A}$ more detailed discussion of this result can be found in my previous publications from 2017, 2018, 2019, and 2020.

${ }^{79}$ Eric R. Kandel, The Age of Insight: The Quest to Understand the Unconscious in Art, Mind and Brain, from Vienna 1900 to the Present, New York: Random House.

${ }^{80}$ Habituation can be tailored to very specific signals. This phenomenon is known as discrimination. The brain distinguishes between multiple similar messages.

${ }^{81}$ In more technical terms, one can say that some new ideas necessarily escape the radar of habituation. These escape variants can push the door open to something new-something that broadens existing horizons and grows until the new growth is checked by new habituation.

${ }^{82}$ Martin A. Nowak, Robert M. May, Virus Dynamics: Mathematical Principles of Immunology and Virology, Oxford: Oxford University Press, 2000, 133-134.

${ }^{83}$ Where two schools are diverse if habituation discriminates between the two and acts against each of them separately.

${ }^{84}$ Martin A. Nowak, Robert M. May, Virus Dynamics: Mathematical Principles of Immunology and Virology, Oxford: Oxford University Press, 2000.

Josef Hofbauer, Karl Sigmund, Evolutionary Games and Population Dynamics, Cambridge: Cambridge University Press, 1998. 
${ }^{85}$ Dan Costa Baciu. "Cultural Life: Theory and Emprical Testing" OSF Preprints (May 2020). DOI: 10.31219/osf.io/ad9fu Note: This article was initially submitted to JSAH in 2016, it was then accepted towards a special issue in Architectural Histories. However, after paying the flights to and hotels in Europe to all participants, the organizers of this special issue did not continue their endeavor due to unknown reasons. Thus the article was resubmitted to JSAH in 2018, 2019, and 2020. The resubmissions were based the editor's suggestion and support. The preprint occurs in order to advance scholarship and avoid further delays. 